\title{
Optimalisasi Penggunaan Media Sosial Bagi Kalangan Remaja Di Sma Negeri 1 Panga Aceh Barat
}

\author{
Agatha Debby Reiza Macella \\ Fakultas Ilmu Sosial dan Ilmu Politik, Universitas Teuku Umar \\ Email: agathadebby@utu.ac.id
}

Submitted: 21 November 2019 Revised: 10 Desember 2019 Accepted: 12 Desember 2019

\begin{abstract}
Advances in technology make it easier for humans in their activities. The internet has become mandatory for use in various aspects of life. Social media users in Indonesia reach 150 million people. Most internet users are aged 15 to 19 years, which is $91 \%$. At present the way to get along with teenagers is not only by direct contact but also indirectly by using media or social networking. The use of social media is sometimes difficult to control either by parents or the school, so there is a need for education for adolescents to be more optimal in using social media for anything positive. The purpose of this mass empowerment activity is to provide understanding to teenagers that social media can provide many positive benefits if we use it in a smart and maximum way, and invites young people to be smart in using social media. The implementation method is through counseling and discussion with high school students 1 Panga. The results of this activity turned out that not all students have social media both Facebook and Instagram because of limitations in accessing. Before this activity the participants only used social media as a means of uploading photos and videos, but after this activity they learned that social media can be used optimally namely to carve out achievements and as a medium to increase personal finances.
\end{abstract}

Keywords: Optimal, Social Media, Adolescent

\begin{abstract}
Abstrak
Kemajuan teknologi mempermudah manusia dalam beraktifitas. Internet menjadi hal yang wajib digunakan dalam berbagai aspek kehidupan. Pengguna media sosial di Indonesia mencapai 150 juta orang. Pengguna internet terbanyak adalah usia 15 hingga 19 tahun yaitu sebesar 91 \%. Saat ini cara bergaul kalangan remaja bukan hanya dengan cara kontak langsung tetapi juga secara tidak langsung yaitu dengan menggunakan media atau jejaring sosial. Penggunaan media sosial inilah yang terkadang sulit untuk dikontrol baik oleh orang tua ataupun pihak sekolah, sehingga perlu adanya edukasi bagi kalangan remaja untuk lebih optimal dalam menggunakan media sosial untuk segala sesuatu yang positif. Tujuan dari kegiatan pemberdayaan massyarak ini yakni untuk memberikan pemahaman kepada kalangan remaja bahwa media sosial dapat memberikan banyak manfaat positif jika kita menggunakan dengan cara cerdas dan maksimal, serta mengajak kalangan remaja untuk cerdas dalam menggunakan media sosial. Metode Pelaksanaan adalah dengan penyuluhan dan diskusi bersama siswa SMA Negeri 1 Panga. Hasil dari kegiatan ini ternyata tidak semua siswa memiliki media sosial baik facebook maupun instagram dikarenakan keterbatasan dalam mengakses. Sebelum kegiatan ini peserta hanya menggunakan media sosial sebagai sarana mengunggah foto dan video saja, namun setelah kegiatan ini mereka mengetahui bahwa media sosial dapat digunakan secara optimal yakni untuk mengukir prestasi dan sebagai media untuk menambah finansial pribadi
\end{abstract}

Kata Kunci: Optimal, Media Sosial, Remaja 


\section{PENDAHULUAN}

Perkembangan

ilmu

pengetetahuan dan teknologi memberikan pengaruh yang begitu besar bagi kemajuan peradaban manusia. Salah satunya adalah maraknya penggunaan internet di seluruh dunia termasuk Indonesia. Apalagi dengan adanya revolusi industri 4.0 bahwasanya teknologi menjadi hal penting untuk menunjang segala aspek kehidupan masyarakat. Kemajuan teknologi yang hingga saat ini digunakan untuk mempermudah manusia dalam beraktifitas adalah internet.

Internet menjadi hal yang wajib digunakan dalam berbagai aspek kehidupan. Apalagi internet merupakan salah satu media bagi kita untuk belajar tentang banyak hal mulai dari sekedar hiburan seperti film, lagu, cerita namun juga dalam hal pencarian data dan informasi yang nantinya dipergunakan untuk dijadikan sebagai referensi. Kementerian Komunikasi dan Informatika (Kemenkominfo) mengungkapkan pengguna internet di Indonesia saat ini mencapai 63 juta orang, sementara dari hasil riset Wearesosial Hootsuite pada Januari 2019 pengguna media sosial di Indonesia mencapai 150 juta atau sebesar $56 \%$ dari total populasi, kemudian pengguna media sosial mobile mencapai 130 juta atau sekitar $48 \%$ dari populasi.
Semakin banyaknya pengguna internet mengindikasikan bahwa media sosial saat ini menjadi bagian penting dalam hidup mayarakat, dimana proses interaksi sosial bukan hanya terjadi secara nyata tetapi juga di dunia maya seperti media sosial. Melalui media sosial seseorang dapat berbagi informasi, mencurahkan

perasaan, berpendapat mengenai permasalahan sosial masyarakat ataupun untuk membagikan komentar. Tidak dapat dipungkiri bahwa media sosial memberikan pengaruh yang besar bagi kehidupan seseorang. Seseorang yang sebelumnya biasa saja dan tidak populer bisa menjadi orang yang luar biasa dan populer hanya dalam waktu singkat melalui media sosial.

Media sosial telah banyak merubah dunia. Media sosial juga mampu untuk memutarbalikkan pemikiran dan teori yang ada. Tingkatan atau level komunikasi melebur dalam satu wadah yang disebut jejaring sosial/media sosial. Konsekuensi yang muncul juga wajib diwaspadai, dimana media sosial media kini mampu menghapus batasan-batasan manusia untuk bersosialisasi, tak ada lagi batas antara jarak dan waktu, dengan media sosial ini manusia dimudahkan untuk berkomunikasi satu sama lain dimana saja dan kapan saj mereka butuhkan sekalipun berada di 
tempat yang berjarak cukup jauh antara satu dengan yang lain, baik itu siang maupun malam.

Sehubungan dengan penggunan media sosial untuk media aktualisasi diri, begitu pula bagi kalangan remaja, dimana mereka sangat membutuhkan tempat untuk mengaktualisasikan dirinya. Rata rata pengguna menggunakan internet selama 3 jam 23 menit sehari. Seringkali remaja beranggapan bahwa semakin aktif dirinya di media sosial maka mereka semakin gaul dan up to date akan segala situasi dan kondisi terkini yang sedang menjadi trend. Sedangkan remaja yang tidak mempunyai media sosial dianggap ketinggalan jaman dan kurang gaul.

Dilihat dari pengertian dasar nya remaja berasal dari istilah adolescence atau remaja berasal dari kata latin (adolescene), kata bendanya adolescentia yang berarti remaja yang berarti "tumbuh" atau "tumbuh menjadi dewasa". Sementara itu Jhon W. Santrock, memberikan pengertian bahwa masa remaja (adolescence) ialah periode perkembangan transisi dari masa kanak-kanak hingga masa dewasa yang mencakup perubahanperubahan biologis, kognitif, dan sosial emosional

Berdasarkan data BPS tahun 2018 , dari 143 juta jiwa anak muda, 54 persen itu sudah menggunakan internet. Sebesar 90,61 \% anak muda masih memanfaatkan internet hanya untuk media sosial dan jejaring sosial. Asosiasi Penyelenggara Jasa Internet Indonesia (APJII) pada Mei 2019 merilis bahwa pengguna internet terbanyak ada pada usia 15 hingga 19 tahun yaitu sebesar $91 \%$ dari 171,7 Juta pengguna internet di Indonesia. Kalangan remaja menggunakan media sosial untuk memposting kegiatan pribadi, curahan hati, serta foto \& video bersama teman maupun keluarga. Hal tersebut didukung dengan adanya survei bahwa $88 \%$ pengguna media sosial di Indonesia mengakses youtube. Indonesia sendiri menampati peringkat 3 pengguna instagram terbanyak sedunia, dan peringkat ke-empat pengguna facebook di dunia.

Melalui media sosial siapapun bebas berkomentar dan menyalurkan pendapatnya tanpa rasa khawatir. Hal ini dikarenakan dalam internet khususnya media sosial sangat mudah memalsukan jati diri atau melakukan kejahatan. Padahal dalam perkembangannya di sekolah, remaja berusaha mencari identitasnya dengan bergaul bersama teman sebayanya.

Namun saat ini cara bergaul kalangan remaja bukan hanya dengan cara kontak langsung tetapi juga secara tidak langsung yaitu dengan menggunakan media atau jejaring sosial. Penggunaan media sosial inilah yang terkadang sulit untuk dikontrol baik oleh orang tua ataupun pihak sekolah, sehingga 
perlu adanya edukasi bagi kalangan remaja untuk lebih optimal dalam menggunakan media sosial untuk segala sesuatu yang positif.

Fase Remaja menurut Hurlock bahwa awal masa remaja adalah mulai dari usia 13-16 tahun atau 17 tahun, dan akhir masa remaja bermula dari usia 16 atau 17 tahun sampai 18 tahun, yaitu usia matang secara hukum. Sedangkan Konopka oleh Syamsu Yusuf, menjelaskan bahwa masa remaja dibagi menjadi beberapa fase, (1) Remaja awal usia 12-15 tahun; (2) Remaja Madya usia 15-18 tahun; dan (3) Remaja Akhir usia 18-22 tahun.

Adapun telah dilakukan beberapa penelitian terkait dengan pengaruh media sosial terhadap perubahan sosial masyarakat di Indonesia oleh Anang Sugeng Cahyono, dimana fokus penelitian adalah melihat perubahan sosial yang terjadi di masyarakat akibat dari adanya media sosial. Kemudian penelitian yang dilakukan oleh Fahlepi Roma Doni berjudul perilaku penggunaan media sosial di kalangan remaja. Dimana pokok bahasan dalam penelitian tersebut adalah melihat perilaku remaja yang ditimbulkan akibat penggunaan media sosial. Selain itu, penelitian lainnya yang berkaitan dengan media sossial juga dilakukan oleh I Gusti Ngurah Aditya Lesmana yang berjudul Analisis pengaruh media sosial twitter terhadappembentukan Brand Attachment (Studi: PT. XL
Axiata). Di mana dalam penelitian tersebut bertujuan untuk melihat pengaruh media sosial sebagai media pemasaran bagi PT. XL Axiata. Dari beberapa peneitian yang sudah dilakukan sebelumnya dan berdasarkan latar belakang permasalahan yang telah diuraikan di atas menjadi dasar kegiatan pemberdayaan masyarakat ini dilakukan di SMA Negeri 1 Panga, mengingat usia SMA ini adalah usia remaja yang belum matang secara hukum.

Kegiatan ini bertujuan untuk memberikan pemahaman kepada kalangan remaja bahwa media sosial sejatinya dapat memberikan manfaat yang positif jika kita menggunakan dengan cara cerdas dan maksimal. Selain itu tujuan lain dalam kegiatan ini adalah mengajak kalangan remaja untuk cerdas dalam menggunakan media sosial.

\section{METODE PELAKSANAAN}

Metode yang dipakai dalam kegiatan ini adalah penyuluhan, serta diskusi kepada siswa siswi SMA Negeri 1 Panga. Alat yang digunakan antra lain laptop dengan dilengkapi LCD projector.

\section{HASIL DAN PEMBAHASAN}

Kegiatan penyuluhan ini bertemakan optimalisasi penggunaan media sosial bagi kalangan remaja ini telah dilaksanakan pada tanggal 7 November 2019. Peserta pada saat 
pelaksanaan kegiatan sangat antusias mengikuti kegiatan hingga selesai. Para peserta sebagian besar adalah pengguna media sosial khususnya instagram dan facebook. Sebelum adanya kegiatan penyuluhan ini mayoritas peserta menggunakan media sosial hanya sebatas untuk mengaktualisasikan diri mereka melalui upload foto amupun video diri mereka sendiri. Padahal sejatinya media sosial memliki banyak manfaat positif untuk membangun.

Jejaring sosial merupakan situs dimana setiap orang bisa membuat web page pribadi, kemudian terhubung dengan teman-teman untuk berbagi informasi dan komunikasi. Jejaring sosial terbesar antara lain Facebook, Path, Instagram, myspace dan twitter. Jika media tradisional menggunakan media ceak dan media broadcast, maka media sosial menggunakan internet. Media sosial mengajak siapa saja yang tertarik untuk berpartisipasi dengan member kontribusi dan feedback/umpan balik secara terbuka, memberi komentar, serta membagi informasi dalam waktu yang cepat dan tak terbatas.

Media sosial merupakan media online dengan para penggunanya bisa dengan mudah berpartisipasi, berbagi, dan menciptakan isi meliputi blog, jejaring sosial, forum maupun dunia virtual. Blog dan jejaring sosial merupakan bentuk media sosialyang paling umum digunakan oleh masyarakat di seluruh dunia. Adapun pendapat lain mengatakan bahwa media sosial sebagai media online yang mendukung interaksi sosial dan media sosial menggunakan teknologi berbasis web yang mengubah komunikasi menjadi dialog interaktif. Andreas Kaplan dan Michael Haenlein mendefinisikan media sosial sebagai “sebuah kelompok aplikasi berbasis internet yang membangun di atas dasar ideologydan teknologi Web 2.0, dan yang memungkinkan penciptaan dan pertukaran "usergenerated content". Jejaring sosial merupakan situs dimana setiap orang bisa membuat web page pribadi, kemudian terhubung dengan teman-teman untuk berbagi informasi dan berkomunikasi. Jejaring sosial terbesar antara lain Myspace Facebook,dan Twitter. Jika media tradisional menggunakan media cetak dan media broadcast, maka media sosial menggunakan internet. Media sosial mengajak siapa saja yang tertarik untuk berpertisipasi dengan memberi kontribusi dan feedback secara terbuka, memberi komentar, serta membagi informasidalam waktu yang cepat dan tak terbatas. Ardianto dalam buku Komunikasi 2.0 mengungkapkan, bahwa media sosial online, disebut jejaring sosial online bukan media massa online karena media sosial memiliki 
kekuatan sosial yang sangat mempengaruhi opini publik yang berkembang di masyarakat. Menurut Antony Mayfield (2008), media sosial adalah media dimana penggunanya dengan mudah berpartisipasi di dalamnya, berbagi dan menciptakan pesan, termasuk blog, jejaring sosial, wiki/ensiklopedia online, forumforum maya, termasuk virtual worlds (dengan avatar dan karakter 3D). Saat teknologi internet dan mobile phone makin maju maka media sosial pun ikut tumbuh dengan pesat. Kini untuk mengakses instagram misalnya, bisa dilakukan dimana saja dan kapan saja hanya dengan menggunakan sebuah mobile phone. Demikian cepatnya orang bisa mengakes media sosial mengakibatkan terjadinya fenomena besar terhdap arus informasi tidak hanya di negara-negara maju, tetapi juga di Indonesia.

Media sosial memiliki beberapa fungsi, diantaranya (1) Memperluas interaksi sosial manusia menggunakan internet dan teknologi web; (2) Mendukung demokratisasi pengetahuan dan informasi; (3) Mentransformasi manusia dari pengguna isi pesan menjadi pembuat pesan itu sendiri.

Adapun dampak positif dari media sosial diantaranya menampilkan identitas diri melalui foto dan biodata diri yang diunggah; (2) mengekspresikan diri melalui tulisan status, foto dan video yang diunggah ke media sosial; (3) hobi tersalurkan secara positif . Tentunya hal ini berkaitan dengan minat dan bakat dari pengguna media sosial baik itu dibidang seni kreatifitas seperti fotografi, barang kesenian, kuliner, travelling, dan sebagainya. Sehingga konten dalam media sosial yang dimiliki juga terkait dengan hobi yang dimiliki; (4) mengajak orang lain untuk melakukan hal positif. Hal ini berkaitan juga dengan berbagai aspek kehidupan seperrti kesehatan, pendidikan, lingkungan, budaya, dan sebagainya; mengukir Prestasi. Hal inilah yang belum tentu setiap pengguna bisa melakukannya, dan mau untuk mencoba memulainya; meningkatkan penjualan produk/ jasa. Sudah banyak sekali produk dan jasa yang dipasarkan melalui media sosial bahkan dinilai lebih efektif menjual melalui media sosial dibandingkan melalui penjualan langsunga di toko atau pasar; (7) populer, popularitas seseorang untuk saat ini dapat dimulai dengan seberapa sering mengunggah foto maupun video yang unik sehingga dapat menjadi viral dan trending topic dalam waktu singkat, maka dari situlah popularitas penggunanya pun juga ikut meningkat; dan (8) mendapatkan penghasilan. Poin ini berkaitan dengan penggunaan media sosial sebagai sarana penjuala produk dan 
jasa, juga berungan dengan popularitas pemilik akun media sosial. Seperti Youtubers ataupun Selebgram yang memiliki banyak pengikut maka akan banyak juga perusahaan bahkan juga mereka yang punya usaha untuk menjadikan menjadikan Youtubers ataupun selebgram untuk memasarkan produk/jasnya melalui akun mereka, sehingga dari situlah mereka memperoleh penghasilan.

Selain dampak positif, media sosial juga tidak terlepas dari beberapa dampak negatif, seperti (1) Produktivitas menurun, hal itu terjadi karena durasi penggunaan internert yang terlalu lama sehingga mengakibatkan kurangnya jam tidur malam. Kurangnya tidur mengakibatkan menurunnya konsentrasi sehingga nilai atau prestasi menurun; (2) Kesehatan mental menurun, dikarenakan seseorang menggunakan media sosial bukan hanya untuk update status, namun melihat status orang lain kemudian dia membandingkan dengan dirinya, makin lama percaya dirinya menurun sehingga si pengguna mengalami depresi dan stress; (3) Terjadinya tindak kejahatan; (4) Munculnya banyak akun palsu dan berita hoax, hal ini dikarenakan semakin banyaknya orang dengan bebas menggunakan media sosial sehingga peluang untuk munculnya akun-akun palsu yang terkadang juga menyebarkan informasi yang tidak akurat bahkan pembohongan publik. Hal ini perlu diwaspadai apalagi untuk kalangan remaja yang masih labil.

Dalam kegiatan penyuluhan ini, disampaikan juga penggunaan media sosial secara optimal dengan cara membuat konten sosial media yang bisa menjangkau semua orang, membuat konten yang membahas topik tertentu, seperti tentang budaya, pendidikan, tempat wisata, atau cinta lingkungan, kuliner, atau fashion. Menampilkan konten dengan konsep baru atau inovasisehinggamenarikpenggunan lain untuk melihat bahkan selalu mengikuti setiap unggahannya. Membuat daftar unggahan yang menarik. Daftar ini bisa dilakukan secara berkala, misalnya setiap satu minggu sekali untuk membuat tema content unggahan.

Selanjutnya, membuat website yang membahas topik topik terkini ataupun bergerak dibidang pendidikan, memastikan astikan membuat format postingan yang bagus. Membagikan informasi yang bermanfaat, informasi ini dapat berupa foto maupun video disertai dengan penjelasan berupa data yang akurat yang mendukung kebenaran dari informasi yang diberikan. Menggunakan media sosial untuk hal-hal yang positif seperti membagikan informasi terkini, berbagi tips dalam membuat kerajinan ataupun memasak makanan dan minuman, 
Menggunakan media sosial sebagai media belajar, artinya belajar bukan hanya di kelas ketika mendengarkan penjelaan dari guru namun juga bisa melalui media sosial. Selanjutnya, menggunakan media sosial untuk mempromosikan diri ataupun produk dan jasa yang dimiliki, serta bisa juga digunakan untuk mengkampanyekan sesuatu yang tujuannya untuk mengedukasi dan mengajak masyarakat khususnya sesama remaja untuk respect terhadap masalah sosial yang terjadi di sekitar mereka baik dibidang pendidikan, kesehatan, kemanusiaan, lingkungan, keadilan dan sebagainya. Berikut terlampir dokumentasi penyajian materi pada saat kegiatan yang berlangsung di SMA N 1 Panga Aceh Barat.

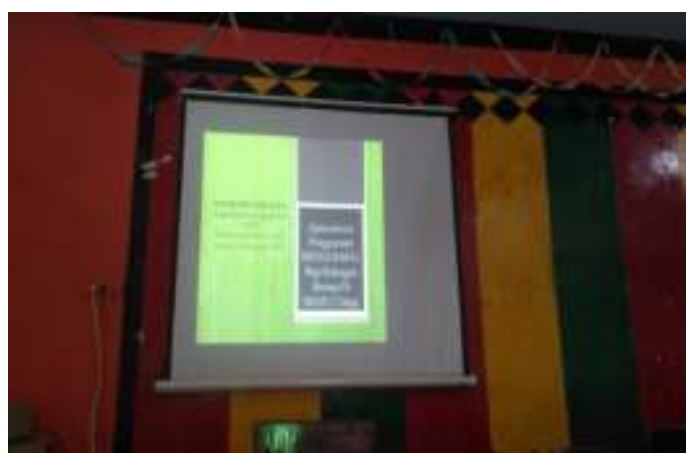

Gambar 1. Materi Penyuluhan

Adapun temuan yang
didapatkan ketika kegiatan
dilaksanakan bahwa ternyata tidak
semua siswa memiliki media sosial

\section{PENUTUP}

Kegiatan penyuluhan tentang optimalisasi pengguna media sosial baik facebook maupun instagram dikarenakan keterbatasan dalam mengakses. Ada beberapa siswa yang tidak memiliki akun media sosial apapun. Selain itu jika sebelum kegiatan ini para peserta hanya menggunakan media sosial sebagai sarana untuk upload foto dan video saja, namun dengan kegiatan ini mereka mengetahui bahwa media sosial dapat digunakan secara optimal bahkan bukan hanya untuk mengukir prestasi namun juga sebagai media untuk menambah finansial pribadi. Berikut turut disajikan gambar 2 saat kegiatan penyuluhan berlangsung dan diikuti oleh seluruh siswa dan siswi kelas XII SMA N 1 Panga.

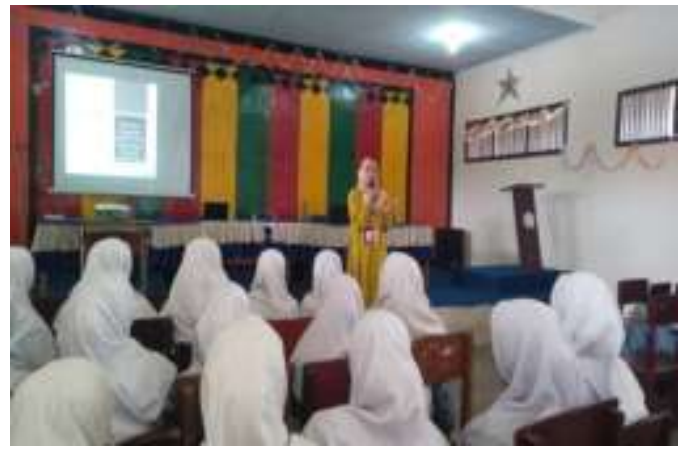

Gambar

2. Kegiatan Penyuluhan Penggunaan Media Sosial

bagi kalangan remaja ini bertujuan untuk memberikan pemahaman kepada kalangan remaja bahwa media sosial sejatinya dapat memberikan manfaat yang positif jika kita 
menggunakan dengan cara cerdas dan maksimal. Selain itu tujuan lain dalam kegiatan ini adalah mengajak kalangan remaja untuk cerdas dalam menggunakan media sosial. Hasil dari kegiatan ini didapatkan bahwa peserta semakin memahami bahwa media sosial bukan hanya sebagai media untuk mengunggah foto dan video, namun banyak hal lain yang bermanfaat salah satunya adalah untuk mengukir prestasi dan bisa mendapatkan tambahan finansial.

Berdasarkan hasil temuan diatas kegiatan selanjutnya dapat dilakukan dengan memberikan pelatihan kepada kalangan remaja untuk dapat membuat blog pribadi sebagai sarana menulis, selain itu juga diberikan pelatihan untuk cara menulis yang baik dan benar. Serta pelatihan untuk membuat uanggahan baik video ataupun tulisan yang positif sebagai bentuk simpatik kalangan remaja terhadap masalah sosial yang terjadi di sekitar mereka.

\section{DAFTAR PUSTAKA}

Cahyono, A. S. (2016). Pengaruh Media Sosial Terhadap Perubahan Sosial Masyarakat di Indonesia. Publiciana, IX.

Doni, F. R. (2017). Perilaku Penggunaan Media Sosial Pada Kalangan Remaja. Indonesia Journal on Software Engineering, III.
Hurlock, E. B. (2003). Psikologi

Perkembangan. Jakarta:

Erlangga.

Lesmana, I. G. (2012). Analisi

Pengaruh Media Sosial Twitter Terhadap Pembentukan Brand Attachment (Studi: PT. XL Axiata). Jakarta: Universitas Indonesia.

N, S. (2005). Kenakalan Remaja. Jakarta: Rineka Cipta.

Rustian, R. S. Pengertian media sosial. Retrieved November 13, 2019, from sosmedkini.wordpress: http://sosmedkini.wordpres s.com/pengertian-mediasosial/

Santrock, J. W. (2002). Adolescence Perkembangan Remaja. Jakarta: Erlangga.

W, Sarwono. S. (2004). Psikologi Remaja. Jakarta: PT. Raja Grafindo Persada.

Yusuf, S. (2000). Psikologi Perkembangan Anak dan Remaja. Bandung: Remaja Rosdakarya. 